\title{
Prosecutorial Discretion and Republican Non-Domination
}

\section{Dustin Crummett ${ }^{1}$ (D)}

Accepted: 25 August 2020 / Published online: 4 September 2020

(C) The Author(s) 2020

\begin{abstract}
Prosecutors in the US legal system have great power to interfere at their discretion in the lives of citizens, and face relatively few checks on the exercise of this discretion. The vast scope of the criminal law provides a pretext for prosecuting nearly anyone. Meanwhile, other features of the legal system, such as the way plea bargains are structured and the doctrine of prosecutorial immunity, further increase prosecutorial power. And existing institutional restraints on prosecutorial abuses, such as democratic accountability, the grand jury system, and the possibility of a selective prosecution defense, are mostly ineffectual. I draw on republican political theory, including insights from Philip Pettit and Elizabeth Anderson, to argue that this state of affairs gives prosecutors dominating, and therefore unjust, power over vast swathes of the public. I then survey some potential institutional changes which might help ameliorate the problem.
\end{abstract}

Keywords Republicanism $\cdot$ Philosophy of law $\cdot$ Petit $\cdot$ Anderson $\cdot$ Overcriminalization

\section{Introduction}

Sami Omar al-Hussayen, a Saudi Arabian immigrant to the US, was arrested in February 2003. He helped run websites for several Muslim charities, and some of these websites linked to other websites containing pro-Jihadi statements. For this, federal prosecutors accused him of providing material support for terrorism. (David Cole, an expert in terrorism law, has called the material support provision of the Patriot Act the "linchpin" of anti-terrorism prosecutions, "precisely because it doesn't require proof that an individual engaged in any sort of terrorist act or even supported any terrorist activity.") The jury, which was given forceful instructions by the judge about the scope of the First Amendment, quickly acquitted al-Hussayen on the terrorism charges. But in the course of investigating him, prosecutors also came to believe that al-Hussayen had violated certain immigration laws and charged him on those counts, too. The

Dustin Crummett

dustin.crummett@gmail.com

1 Ludwig-Maximilians-Universität München, Geschwister-Scholl-Platz 1, 80539 Munich, Germany 
jury acquitted him on some of the immigration charges but deadlocked on others. Rather than go through another trial, al-Hussayen reached a deal with prosecutors whereby he agreed to be deported back to Saudi Arabia (Silverglate 2009, 237-240).

Now consider a case from Suffolk County, New York, where several local Democratic officials sued the Republican district attorney on the grounds that he'd filed spurious indictments against them in an attempt to discredit them for political reasons. The court ultimately dismissed the case, not because it rejected their factual claim, but because "absolute immunity shields [the DA's] performance of advocative functions regardless of motivation" (Bernard $v$. County of Suffolk, 356 F.3d 495, 498 (2nd Cir. 2004)). This was an invocation of the doctrine of prosecutorial immunity, which protects prosecutors from civil liability for actions taken in the course of prosecuting a case.

These two cases help illustrate an important fact: if a prosecutor decides they want to go after someone-due to, say, Islamophobia, racism, personal animosity, dislike of one's political views, a sense that one must be up to no good, a desire to appear "tough" on a certain issue, or whatever-there's a good chance that they'll be able to seriously disrupt the life of the person in question, and those they target may have little recourse. As one scholar (Reiss 1987, 1365) puts it, "Few officials can so affect the lives of others as can prosecutors. Yet few operate in a vacuum so devoid of externally enforceable constraints." A number of attorneys, legal scholars, and journalists have criticized this power (e.g., Healy 2004; Lynch 2009; Keenan et al. 2011; Reynolds 2013; Silverglate 2009; Cottone 2014), but it has received less philosophical attention. Here, I critique it from the perspective of republican political theory. ${ }^{1}$ As I understand it, republicanism regards eliminating domination with respect to basic rights as necessary for social justice, ${ }^{2}$ where "Someone, A, will be dominated in a certain choice by another agent or agency, B, to the extent that B has a power of interfering in the choice that is not controlled by A" $(2012,50) .^{3}$ I claim that the current American legal system gives prosecutors dominating, and therefore unjust, discretionary power over very many people: they can interfere, at will and with relative impunity, in the exercise of the basic freedoms of very many people, either directly (by, say, imprisoning them) or else through implicit or explicit threats (so that individuals avoid undesired behavior in order to avoid being targeted). ${ }^{4}$ My aim in this paper is to defend this claim, and to explore some institutional changes which might help ameliorate the problem. (No doubt much of what I say will apply to other legal systems, but the American system is the one I know most about.)

Legal scholars have criticized prosecutorial power, or the particular conditions which lead to it, on a number grounds: for instance, they've appealed to considerations of fairness and desert (e.g., Kozinski and Tseytlin 2009, 49-50), to general concerns about due process (e.g.,

\footnotetext{
${ }^{1}$ What I call "republicanism" is sometimes called "neo-republicanism," to distinguish it from historical forms of republicanism (e.g., republicanism as found in the professed values of the ancient Roman republic, or in various early enlightenment figures.)

${ }^{2}$ Pettit (e.g., Pettit 2012) regards eliminating domination as sufficient for social justice. I (like Anderson, who I discuss later) reject this claim, and I don't build it into the definition of the kind of republicanism to which I want to appeal. But my argument should have as much or more purchase for someone who accepts the sufficient claim.

${ }^{3}$ As I explain in section three, agents should be understood as lacking the "power" mentioned in cases where they will face penalties for interference sufficient to keep interference from being a live option, even they retain the "power" to interfere in some other sense.

${ }^{4}$ Note that I am focusing specifically on the discretionary power prosecutors have in virtue of their ability to decide which cases to charge, which penalties to seek, etc. I believe prosecutors also have other powers-such as the ability to easily illegally withhold exculpatory evidence without much risk of facing serious repercussions (cf. Keenan et al. 2011)-which further exacerbate their dominating power. I plan to discuss this in future work.
} 
Reynolds 2013), to Lon L. Fuller's theory of the "internal morality of the law" (Cottone 2014, 150-159), and to economic analysis (159-164). ${ }^{5}$ An important upshot of my republican criticism is that, if the republican approach is correct, the problem is exposed as being much worse than it might otherwise be. Because republicans view it as unjust when one person has the power to interfere with relative impunity in the exercise of another's basic rights, even if they don't actually do so, republicanism implies that very many people are the victims of injustice simply because prosecutors could arbitrarily charge them with a criminal violation. This is true even if this never happens, so that they never, say, receive an unfair punishment or a punishment out of proportion with their desert, or have their legal due process rights violated. A related point is that, while and I many others think prosecutorial abuses are fairly common (c.f. Keenan et al. 2011, 209-213), this isn't essential to my argument. Even if all prosecutors are endowed with tremendous discernment and virtue, so that they never abuse their power, that they could do so without facing serious consequences still constitutes a severe and widespread injustice. ${ }^{6}$

In section two, I discuss some relevant aspects of republican political theory, relying heavily on Philip Pettit's characterization of the view and on Elizabeth Anderson's republican defense of bureaucracy. In section three, I discuss in greater depth the features of the American legal system which lead to prosecutorial domination. Specifically, I first discuss the factors which lead to what I call universal criminalization-i.e., the fact that the American legal code is currently so expansive that nearly everyone routinely violates, or can be interpreted as violating, criminal law, thus giving prosecutors a good chance of finding some violation or other on the part of anyone if they look hard enough. ${ }^{7}$ I then discuss some additional features of the legal system which further exacerbate the dominating power of prosecutors (such as the above-mentioned doctrine of prosecutorial immunity, or the fact that undergoing criminal prosecution is so onerous that even those who aren't convicted still have their lives seriously disrupted). Finally, I discuss the failure of existing safeguards, namely democratic accountability, grand juries, and the "selective prosecution" defense. In section four, I survey some possible solutions. I will not attempt to evaluate these suggestions in any great detail; that would require more space, and more empirical investigation, than is possible here. The point will instead be to show some potential avenues for future investigation. If we can implement these without unduly compromising the other aims of the criminal justice system, we need not accept prosecutorial domination as an unavoidable fact.

\section{Freedom as Non-domination}

I'll now summarize some aspects of republicanism which will be relevant for my project here. For Pettit, the republican political tradition understands the kind of freedom which is of primary political importance as requiring non-domination, where, as mentioned, "Someone, A, will be dominated in a certain choice by another agent or agency, B, to the extent that B has a power of interfering in the choice that is not controlled by A" (Pettit 2012, 50). I might have

\footnotetext{
${ }^{5}$ Of course, a republican might also accept the desert or due process criticisms. They might even claim that avoiding domination is our primary reason for caring about due process.

${ }^{6}$ But see the discussion of whether Pettit's republicanism is overly demanding in section two.

7 What I call "universal criminalization" is sometimes called "overcriminalization." But since "overcriminalization" is a common term with a variety of meanings, some of which are not quite what I want, I thought it best to introduce my own term.
} 
the capacity to interfere with your choice (say, about whether to drive to a certain town) in three ways. First, I might remove an option (perhaps by destroying your car so that you can't drive anywhere.) Second, I might penalize an option to deter you from taking it (perhaps by standing ready to destroy your car if you drive it to town.) Third, I might misrepresent your options (perhaps by successfully bluffing and making you think I will destroy your car if you come to town, even though I won't) so that your actual options are not epistemically available to you (50-56). I can also dominate you without actually interfering with you. If I could interfere, and you have no recourse against me, you are subject to my will, whether or not I actually interfere (61-62).

Freedom as non-domination is stronger than freedom conceived as requiring only the ability to do what you want. (Freedom in this latter sense can be achieved by setting your sights low enough that you only desire to do things you'll be able to do.) Freedom as nondomination is also distinct from freedom conceived as requiring only the ability to choose among a suitable range of options without interference. For republicans, you are less free when someone else could interfere at relatively little cost, even if they do not in fact do so; you are at their mercy, even if they happen to be merciful. Permissive dictators are better than totalitarian ones, but are still bad insofar as they are dictators (Pettit 2012, ch. 1 and 64-67). As mentioned above, this point has important implications for the excessive power of prosecutors, since it implies that their having this power is bad, even if they don't abuse it.

Interference due to domination often seems worse than other factors which might prevent my taking an option. Suppose I know that if I park my car downtown, it will be damaged by hail, so that parking it there is no longer a live option for me. Now suppose, instead, that someone threatens to damage my car if I park it downtown, and I have no recourse in the face of their threat, so that parking downtown is again no longer a live option. Republicans say that the second case seems much worse. In the second case, subject to the arbitrary whims of another, I reasonably feel outraged, vulnerable, and powerless; this kind of domination poses a much greater threat to my dignity, and to my status as a free person, than the hailstorm does. But note that this is true even if there is no actual interference. Maybe I didn't actually want to park downtown, or maybe you could have interfered with my freedom of movement, but graciously refrained. This is, of course, better than a case where you do interfere, but I am still under your power. The special normative significance of domination gives it its prominent place in republican political theory (43-44).

For Pettit, the aim of republican social justice is to ensure, insofar as possible, that citizens are free with respect to their basic liberties (ch. 2). This requires guarding against domination by some citizens over others with respect to the choices that comprise these liberties. The state might protect me from domination by directly stopping attempts to interfere with my choices (for instance, as when a police officer restrains someone trying to attack me) or by imposing penalties (such as civil or criminal penalties) which make interference unattractive enough that it is no longer a live option (69-73). In either case, they no longer count as having the power to interfere with the relevant kind of impunity. Of course, no such method will be perfectly effective. But it is reasonable enough to hope for methods which are effective enough that "you have no good reason to be anxious" (71).

The obvious risk here is that, in empowering some people (politicians, policemen, etc.) with the authority and resources to prevent domination, we will simply create new avenues through which domination can occur. Pettit focuses at length on the question of how we can avoid the state's being a dominating agent, arguing that the right kind of democratic control can do the trick (Pettit 2012). A related but somewhat separate worry is how we can avoid particular 
officials within the state using or abusing their power in order to dominate others. Sadly, democracy itself, even when functioning about as well as one could realistically hope, may not reliably guard against this possibility. The abuse of power may never come to the knowledge of most members of the public. Members of the public may agree with the abuse of power, perhaps because it's directed against members of a stigmatized minority. Or perhaps members of the public know about the abuse and recognize it as an abuse, but this doesn't constitute an effective deterrent-maybe the official is in a "safe" district, or their opponent is even worse. When an official is appointed rather than elected, and so subject only to indirect democratic control, there are even more ways for accountability to fail.

Accordingly, it will be good to consider other institutional steps which might be taken to curb domination by state officials. But first, I'll address a potential worry. Some authors think the republican account of freedom is overly demanding. For instance, Thomas Simpson (2017) argues that republican freedom, as understood by Pettit, is impossible to realize. It is only achievable if we modify the view to say that I'm free even when others will not interfere due to internal checks on their actions-specifically, because they possess civic virtue (sec. 5). If prosecutors in fact tend to possess this sort of civic virtue, my argument that they possess dominating power might be undermined. A referee echoed a similar point: given Pettit's admission that the most we need hope for is that we have "no good reason to be anxious," why think an average American has "good reason to be anxious" about prosecutors, given that the odds of a prosecutor actually using their power against them might be very low? Simpson also suggests that many republican intuitions might be better accounted for by a general social egalitarianism (ibid.; cf. Kolodny 2019). E.g., perhaps a permissive dictator is bad simply due to the social hierarchy between us, rather than because the freedom of the subjects is curtailed.

Rather than defending Pettit's view (which would take too much space), I will give a concessive response here, trying to show that my argument has some force even if these critiques succeed. Suppose we think I'm dominated only if there is some sufficiently high chance of my being interfered with. It seems plausible to think that, even if many Americans are at low risk for prosecutorial interference, many others are not-neither civic virtue nor anything else makes it extremely unlikely that prosecutors will interfere with them. ${ }^{8}$ An obvious candidate class is political dissidents, or those sympathetic to them. Glenn Greenwald (2011) once reported that a number of his readers were reluctant to financially support WikiLeaks lest they "incur criminal liability for materially supporting a Terrorist organization" (as Sami Omar al-Hussayen did). These people in fact were anxious, and I'm not inclined to say they lacked reason for it.

Or consider the situation of young black men. Racial disparities in policing, among other factors, put them at higher risk of being arrested, and so of coming to the attention of a prosecutor (Yankah 2013, 6-7). And if they are arrested, prosecutors are likely to interfere with them much more than with members of many other groups. One study (Rehavi and Starr 2014) found that, controlling for other factors, "blacks receive sentences that are almost 10 percent longer than those of comparable whites arrested for the same crimes," and that "Most of this disparity can be explained by prosecutors' initial charging decisions, particularly the filing of charges carrying mandatory minimum sentences" (ibid., 1320). A report from the non-profit organization The Sentencing Project ("Reducing...", 2008) confirms that "The charging decision represents one of the most critical stages of the criminal justice system,

\footnotetext{
$\overline{{ }^{8} \text { A similar argument-in a different }}$ context-is made by Braithwaite and Pettit 1992, 101-102.
} 
with considerable potential for reducing or expanding racial disparity" (37). Another study (Owens et al. 2017) of indigent defendants in San Francisco found that:

...defendants of color are more likely to be held in custody during their cases, which tend to take longer than the cases of White defendants. Their felony charges are less likely to be reduced, and misdemeanor charges more likely to be increased during the plea bargaining process, meaning that they are convicted of more serious crimes than similarly situated White defendants. In addition, Black and Latinx defendants are more likely to plead guilty (1).

These outcomes result partly from the "compounding decisions of booking officers, prosecutors, public defenders, judges, and probation officers," including the "number, type, and severity of charges that are added to the initial booking by the District Attorney's Office" (2). (See section 3 for a discussion of the role that factors like those mentioned-overbooking, the plea bargaining system, holding defendants pre-trial, etc.-play in rendering individuals vulnerable to domination.) Given that half of African-American men will be arrested before the age of 23 (Brame et al. 2014), a certain individual's odds of experiencing a prosecutor's arbitrary abuse of power may be significant.

Saying that individuals are dominated only when the risk of interference is great enough would undercut my earlier claim that republicanism condemns the extent of prosecutorial power, even if prosecutors are essentially guaranteed never to abuse it. However, it leaves intact my claim that republicanism will regard the problem as worse than it would otherwise be. Many people who aren't actually interfered with by prosecutors are still at an appreciable risk of interference, and so dominated according to this modified republicanism. ${ }^{9}$

Now consider the other suggestion, namely, that republicanism should be replaced by a more general social egalitarianism. Writing about racial discrimination in policing and drawing on work from Pettit, Charles Taylor and the legal theorist Jeffrey Fagan, the legal theorist Ekow Yankah argues that:

...the racial insult in such skewed policing communicates inferiority not only to those under police gaze but to the community at large. Among the important social basis [sic] for self-respect is not just the internally held belief in one's equal status but the knowledge that this belief is widely held. Conversely, that one's status denotes that state officials can interfere with one arbitrarily disseminates an image of one as inferior and subject to domination (Yankah 2013, 7).

\footnotetext{
${ }^{9}$ A referee suggests that modifying republicanism in the "concessive" way I've suggested makes it more plausible, but also less different from ordinary liberalism. Since ordinary liberals agree that abuses of power are bad, they can agree that we should do something in situations where there is a non-negligible chance of an abuse of power. To some extent, this is fine: the more people who can recognize the problem, the better. But this might risk undercutting my claim that republicanism is doing anything distinctive here. However, the point made in the main text is significant here. Liberalism will regard actual interference as significant, and attempt to minimize the risk of interference solely as a means of reducing actual interference. "Concessive" republicanism, meanwhile, regards an appreciable risk of interference as objectionable in itself. Presumably an "appreciable" risk, one which gives you "good reason to be anxious" about such significant forms of interference as prosecutors can employ, could still be pretty low-much less than $50 \%$. So republicans will see many times as many objectionable states of affairs here as liberals. Of course, since everyone agrees that actual interference is worse, there is no algorithmic way of determining from that exactly how much worse the republican will see the problem on balance. But the republican will see it as worse.
} 
If-as some of the above data suggest-prosecutorial discretion similarly has a disproportionately bad impact on African-Americans (or members of other groups), an analogous argument could be leveled against it.

Returning to the question of what institutional measures might keep prosecutors in check brings us to Anderson's (29) egalitarian defense of bureaucracy. Anderson is a social egalitarian. Social egalitarians believe people should stand in equal social relations to one another, and are wary of social hierarchies (ibid.). Anderson regards relationships of domination, as understood by republicanism, to be a form of objectionable social hierarchy, and therefore regards republicanism as a component of egalitarianism. Her egalitarian defense of bureaucracy is aimed at vindicating it as a safeguard against domination, and we may therefore safely treat it as, essentially, a project in republican political theory, even though she thinks that the demands of equality, and social justice more broadly, go beyond republican non-domination (144-146).

Anderson's defense of bureaucracy is spurred by consideration of the abuses possible in patron-client relationships, where such relationships consist "in a relation of personal dependence of the client on the patron, secured by the patron's gratuitous gifts or favours to the client," and where "in return for credit or material goods... clients pledge their personal loyalty and submission to their patron" (151). These relationships constitute a hierarchy insofar as clients must follow their patron's orders, upon pain of having the benefits upon which they depend withdrawn. And this hierarchy is one of domination because the patron's ability to issue and enforce commands is far-reaching and unaccountable, allowing them, if they choose, to restrict the basic rights of their clients: "the patron-client relationship grants superiors wide scope for arbitrary discretion over their subordinates. Few rules constrain the patron's power" (151). Among the examples of dominating patrons which Anderson gives are feudal lords, certain employers (151-152), and public officials in areas "where civil servants treat the discretionary powers of their office as private property" (141). By way of remedy, Anderson suggests the implementation of bureaucratic regimes, which, among other things, constrain the actions of officials via "the rule of law, tied to a principle of efficiency" (155). Officials must have a certain amount of discretion, since no set of rules could precisely specify what they should do in every circumstance. However, rules can constrain this discretion, giving them only the amount of discretion needed to do their job, and no more: for instance, a sergeant can order a private to charge a position, but not to hand over five dollars, the latter being unrelated to the needs which justify the sergeant's authority (ibid.). When such constraints are in place, the power of officials is "not arbitrary, but limited to the ends of office" (ibid.).

Whether the relationship between a prosecutor and someone in their jurisdiction is literally a patron-client relationship may vary. It could be: a prosecutor might well target someone in retaliation for, say, challenging them in an election (see the discussion in section 4.3 of why incumbent DAs often run unopposed). But usually it's not like this. Prosecutors generally don't have direct relationships with those they target in which they demand personal loyalty and obedience, and, unlike patrons, their potential interference with the freedom of others usually takes the form, not of issuing commands which must be followed on pain of losing essential benefits, but rather of arresting, trying, and hopefully imposing criminal penalties on those they target, or threatening to do so. Suppose a prosecutor targets on spurious members of a political group or ethnic he dislikes. This is not a patron-client relationship, even though it is a dominating abuse of power.

But even where there is not a literal patron-client relationship, I claim that there is an important analogy between patrons and prosecutors, in that both have "wide scope for 
arbitrary discretion" over others which is not adequately reined in by formal constraints. In the case of patrons, this is due to a lack of formal rules which constrain their power. In the case of prosecutors, this is partly because those over whom they have power face so many rules that the rules are constantly broken, so that prosecutors have immense discretion over which rules to enforce, and against whom, without formal rules constraining the exercise of that power, so that they can target whoever they wish. What is needed, I claim, is some set of institutional provisions which can tame the discretionary power of prosecutors in the way that ordinary bureaucracy can tame the discretionary power of civil servants who would otherwise be dominating patrons. Some proposals for this will be discussed in section five. But first I will say more about the problem.

\section{Criminalization and Domination}

In this section, I first identify four features of the American legal code in virtue of which universal criminalization-the fact that nearly everyone routinely violates, or can be interpreted as violating, criminal law-obtains. Second, I identify three additional features of the legal system which, in conjunction with universal criminalization, enhance the discretionary power of prosecutors. These features would increase this power on their own, but increase it further in light of universal criminalization. These features may not be the only ones in the legal system which lead to prosecutorial domination, but they are some of the main ones. Third, I explain how prosecutorial power leads to widespread domination. This requires showing how existing measures to prevent prosecutorial abuses are insufficient.

\subsection{Universal Criminalization}

The fact of universal criminalization is illustrated by a game which the law professor Timothy $\mathrm{Wu}$ (2007) describes being played at a federal prosecutor's office in New York:

Junior and senior prosecutors would sit around, and someone would name a random celebrity - say, Mother Theresa or John Lennon. It would then be up to the junior prosecutors to figure out a plausible crime for which to indict him or her. The crimes were not usually rape, murder, or other crimes you'd see on Law \& Order but rather the incredibly broad yet obscure crimes that populate the U.S. Code like a kind of jurisprudential minefield: Crimes like "false statements" (a felony, up to five years), "obstructing the mails" (five years), or "false pretenses on the high seas" (also five years). The trick and the skill lay in finding the more obscure offenses that fit the character of the celebrity and carried the toughest sentences. The, result, however, was inevitable: "prison time."

As $\mathrm{Wu}$ states, universal criminalization is not the result of Americans suddenly committing a rash of the "crimes you'd see on Law \& Order." Rather, it is the result of at least four factors which I identify here.

The first feature in virtue of which universal criminalization obtains is just the fact that there are so many laws. In fact, no one knows how many laws there are. Estimates of the number of federal statutes (i.e., laws passed by Congress) with associated criminal penalties range from 3600 to 4500 (Cottone 2014, 141). When written out, they take up tens of thousands of pages (Healy 2004, vii), and the number increases by dozens every year (Baker 2008). The number 
of regulations made by federal agencies which bear criminal penalties far exceeds this; there may be as many as 300,000 (Reynolds 2015). And this is before even getting into state and local laws. Clearly, no one could possibly be expected to be familiar with more than the tiniest fraction of all the criminal laws there are.

The second feature in virtue of which universal criminalization obtains is that many of these laws regulate aspects of ordinary life, imposing rules which it's easy to break; in the words of Michael Cottone, (Cottone 2014, 141), they target a "wide and varied range of conduct." We could imagine a system with a huge number of laws, all of which simply draw fine distinctions between crimes like murder, assault, larceny, and so on. People living their everyday lives could safely avoid breaking any number of laws like these. Unfortunately, as Wu's description confirms, the American legal code is not like this. For instance, anyone who has ever thrown out junk mail addressed to one of their neighbors but mistakenly delivered to their house has committed obstruction of correspondence, a crime punishable by up to five years' imprisonment under Title 18, Part I, Chapter 83, Section 1702 of the US Code. Or, to take a case of an actual prosecution: in 2007, Lawrence Lewis, the African-American chief engineer at a military retirement home, diverted the backed sewage system into a storm drain to permit the building from flooding. This had long been standard practice at the home; Lewis, his predecessors on the job, and the building's manager all believed the drain led into the municipal waste treatment system, which would have made the act legal. It instead led into a small tributary of the Potomac River, and Lewis was charged with violating the Clean Water Act. Since the act has no mens rea requirement (see the relevant discussion later in this section), his innocent intentions were no excuse. He struck a plea bargain (see the relevant discussion in the next section) and thereby avoided jail time, but still received probation, a $\$ 2500$ fine, and a criminal record for trying to perform his perfectly ordinary job. This humiliated him, given that, in the words of his lawyer, he had "spent his adult life trying to show his daughters that not every African-American man is caught up in the criminal-justice system," and the conviction was a major obstacle in trying to find a new job (Fields and Emshwiller 2011).

There also exist a maze of state and local statutes and regulations. For instance, suppose I sell my friend a truckload of firewood which I chopped. In New Mexico, this is illegal, since firewood can only be sold in cords (i.e., a unit of 128 cubic feet of wood). Nor is this an obscure rule which would never be enforced: the New Mexico Department of Agriculture's website ("Buying...", 2015) even provides a tip line and encourages citizens to report violations of this law, so I'd better hope I don't mention what I've done to a busybody neighbor.

The third feature is that some federal laws are extremely vague (or, in Wu's terms, "incredibly broad.") They can be interpreted as ruling out a very wide range of activities, and it isn't always clear in advance what would count as complying with them. Recall the case of Sami Omar al-Hussayen, prosecuted for material support of terrorism for linking to websites which expressed the wrong views. At least al-Hussayen was ultimately acquitted. In 2010, the Supreme Court ruled against the Humanitarian Law Project, which wanted to provide designated terrorist organizations such as the Kurdistan Workers' Party with advice on peacefully pursuing their political aims. Despite the fact that this advice would be intended to help these groups turn away from violence, and could not tangibly be used to facilitate terrorism, the court ruled that it, too, constituted material support for terrorism (Barnes 2010; Silverglate xiv$\mathrm{xvi}$ ). In the US, the so-called "vagueness doctrine" allows courts to strike down laws which are so vague that they fail to provide fair notice in advance of which actions are illegal (Vagueness 
Doctrine 2018). However, courts have often not been aggressive in doing so. For instance, the Supreme Court, in ruling against the Humanitarian Law Project, implausibly declared that a "person of ordinary intelligence" should have been able to tell that their proposed activities constituted material support of terrorism (Silverglate 2009, xv).

The fourth feature is the proliferation of crimes which lack a mens rea requirement (i.e.,. a requirement that the defendant be shown to have acted with a "guilty mind"). Many of these are "regulatory crimes," those which "enforce and support administrative schemes," such as, say, the crimes specified by various tax laws; they contrast with common law crimes such as murder and theft (Cottone 2014, 140). Citizens are generally presumed to know what the law is-the source of the famous claim that "ignorance of the law is no excuse" (144-149). Of course, there's a question about whether this presumption is reasonable, in light of a legal code which is so complex that no one even knows how many laws there are (cf. Cottone 2014), and about whether it is just more broadly (cf. Husak 2016). But crimes with a mens rea requirement do at least necessitate that the defendant knew or should have known they were doing something which is in fact illegal, even if they didn't know that type of action was illegal. Crimes without mens rea requirements, however, can allow for prosecution even in situations where non-culpable ignorance of the facts of a case mean that someone who knew the law wouldn't have realized that it prohibited what they were doing. This is why, for instance, the fact that Lawrence Lewis and everyone around him didn't realize that the storm drain in question led into a river was no excuse. This is also how Bobby Unser wound up with a criminal conviction under the Wilderness Act when, lost in a snowstorm, he accidentally drove his snowmobile onto a protected area while looking for help (141). More broadly, it means that the vulnerability of the average person to prosecution is greatly increased: the criminal law possesses such scope and complexity that it's impossible for an average person to know whether they might violate it while going about their day, but, legally speaking, this is often no defense.

\subsection{Further Features}

There are at least three further features of the legal system which significantly increase the power of prosecutors to interfere with the lives of those they choose. They would increase this power somewhat on their own, but their impacts are often magnified by the existence of universal criminalization. The first feature is the fact that, as the saying goes, "the process is punishment" when it comes to criminal investigation and prosecution. Suppose a prosecutor brings charges against someone based on a strained interpretation of a law, and the defendant is ultimately vindicated in court. The defendant has still had to spend a huge amount of time and possibly money, has been embarrassed before the community, and so on. The prosecutor therefore managed to interfere significantly with the defendant's life, imposing a significant cost on them, despite failing to secure a conviction.

This factor is especially pressing for defendants who are denied or are unable to make bail, and who are therefore imprisoned while awaiting trial. Nearly half a million people are imprisoned while awaiting trial at any given time in the US. Such defendants spend an average of nearly two months in jail waiting for their trials-enough, say, to lose your job, and maybe your apartment-and some spend years waiting. While imprisoning those awaiting trial is sometimes necessary due to their being a flight risk or for reasons of public safety, there are very many cases where it cannot plausibly be justified on these 
grounds: for instance, a report several years ago from an advocacy organization, the Vera Institute, estimated that a stunning $41 \%$ of the inmates in New York City were awaiting trial on misdemeanor charges due to being unable to pay a bail of $\$ 2500$ or less. Indeed, in cases like this, the process is often liable to worse than the actual punishment for crime, which may be only probation or community service (Ingraham 2015).

The second feature involves the American plea bargaining system. Thanks in part to universal criminalization, prosecutors can charge defendants with a wide array of crimes, some of which may carry extremely steep penalties. Prosecutors can then offer defendants the opportunity to plead guilty on some lesser charge. Faced with the risk of being found guilty of something or other and handed a far worse penalty, even innocent defendants have a strong incentive to accept the bargain; as Silverglate (2009, xliv) puts it, "Prosecutors are able to structure plea bargains in ways that make it nearly impossible for normal, rational, self-interest calculating people to risk going to trial." And, indeed, this tactic generally works: an astonishing $94 \%$ of state level, and $97 \%$ of federal level, felony convictions result from guilty pleas (Yoffe 2017), as compared to fewer than $80 \%$ at the federal level thirty years ago ("The Trial...", 2018, 1). While individuals may have various reasons for pleading guilty, a report from the National Association of Criminal Defense Lawyers ("The Trial...", 2018, 5) argues that:

Guilty pleas have replaced trials for a very simple reason: individuals who choose to exercise their Sixth Amendment right to trial face exponentially higher sentences if they invoke the right to trial and lose. Faced with this choice, individuals almost uniformly surrender the right to trial rather than insist on proof beyond a reasonable doubt, defense lawyers spend most of their time negotiating guilty pleas rather than ensuring that police and the government respect the boundaries of the law including the proof beyond a reasonable doubt standard, and judges dedicate their time to administering plea allocutions rather than evaluating the constitutional and legal aspects of the government's case and police conduct.

This system allows prosecutors to target many more people than they otherwise could (since they don't need to spend limited resources on trials) and to target many particular individuals who they otherwise could not (since they don't actually need to prove that someone committed a crime in order to secure a conviction). It also allows them to avoid public scrutiny, since cases which are resolved by plea bargains receive less attention than those which go to trial (Silverglate 2009, xliv-xlvi). Finally, since "the vast majority of known instances of prosecutorial misconduct come to light only during the course of a drawn-out trial or appellate proceeding" (Keenan et al. 2011, 210), plea bargains allow prosecutors to prevent misconduct from being discovered at all by avoiding such trials.

The third feature concerns the doctrine of prosecutorial immunity, which, as I mentioned in the introduction, prevents prosecutors for being sued for actions related to prosecuting a case (Reynolds 2013, 106). Of course, this is meant to ensure that prosecutors can do their jobs without fear of reprisals, as well as to ease the burden on the judicial system which might result if defendants could bring lawsuits against prosecutors willy-nilly. However, in the current context, it is cause for concern. This is because, to put the matter in republican terms, it removes a tool which those who are the victims of prosecutorial abuses might otherwise use to control the power of prosecutors to interfere with their actions. 


\subsection{Domination}

In 1940, Robert H. Jackson, then the Attorney General and later a Supreme Court Justice, said that:

One of the greatest difficulties of the position of prosecutor is that he must pick his cases, because no prosecutor can even investigate all of the eases in which he receives complaints... If the prosecutor is obliged to choose his cases, it follows that he can choose his defendants. Therein is the most dangerous power of the prosecutor: that he will pick people that he thinks he should get, rather than pick cases that need to be prosecuted. With the law books filled with a great assortment of crimes, a prosecutor stands a fair chance of finding at least a technical violation of some act on the part of almost anyone. In such a case, it is not a question of discovering the commission of a crime and then looking for the man who has committed it, it is a question of picking the man and then searching the law books, or putting investigators to work, to pin some offense on him. It is in this realm, in which the prosecutor picks some person whom he dislikes or desires to embarrass, or selects some group of unpopular persons and then looks for an offense, that the greatest danger of abuse of prosecuting power lies. It is here that law enforcement becomes personal, and the real crime becomes that of being unpopular with the predominant or governing group, being attached to the wrong political views, or being personally obnoxious to or in the way of the prosecutor himself (Jackson 1940, 19).

Of course, as the legal code has grown over time, the ability of prosecutors to "pick the man and then... pin some offense on him" has likely grown as well. A similar point, honing in more specifically on the dangers of universal criminalization, was made by the famed legal scholar Henry M. Hart in Hart 1958 (428-429):

The breadth of discretion we entrust to the police and prosecuting attorneys in dealing with individuals is far greater than that entrusted to any other kinds of officials and less subject to effective control. This discretion presents obvious difficulties in securing the lawful and equal administration of law... The stupidity and injustice of the thoughtless multiplication of minor crimes receives its most impressive demonstration in police stations and prosecutors' offices. Invariably, staffs are inadequate for enforcement of all the criminal statutes which the legislature in its unwisdom chooses to enact. Accordingly, many of the statutes go largely unenforced. To this extent, their enactment is rendered futile. But it proves also to be worse than futile. For statutes usually do not become a complete dead letter. What happens is that they are enforced sporadically, either as a matter of deliberate policy to proceed only on private complaint, or as a matter of the accident of what comes to official attention or is forced upon it. Sporadic enforcement is an instrument of tyranny when enforcement officers are dishonest.

As I've suggested, one implication of the republican framework which I bring to bear here is that the problem is even worse than Hart realizes: sporadic enforcement is an instrument of tyranny even when enforcement officers are not dishonest, since it is enough for domination that someone has the ability to interfere with relative impunity in the exercise of my basic freedoms.

More specifically, to the extent that prosecutors really can "pick the man and then... pin some offense on him," they dominate those to whom they can do this in at least two ways. 
First, they have the ability to interfere with the exercise of many of the basic rights of such people-for instance, the right to move about freely, or to keep their own money-by arresting them, trying them, and, potentially, fining or imprisoning them. (Of course, criminals often forfeit certain basic rights in virtue of their crimes. But it isn't plausible to think that the significant majority of the population has done so, just in virtue of the American legal system having the qualities described in section 4.1.) This is analogous to a case where you directly interfere with my driving downtown by restraining me, or by destroying my car. As I have mentioned, an important upshot of republicanism is that this first power holds in general, and therefore constitutes widespread domination, regardless of how often prosecutors actually employ it. Second, that prosecutors possess the first power may deter some people from certain exercises of their basic rights. For instance, seeing the fate of Sami Omar al-Hussayen might reasonably make others reluctant to work with or advocate for Islamic organizations, lest they be accused of some unpredictable crime. This is analogous to a case where my freedom to drive downtown is restricted by the fact that you might destroy my car if I do.

The American judicial system contains at least three main features aimed at preventing prosecutorial abuses. ${ }^{10}$ Unfortunately, none of them successfully prevents widespread domination. One is democratic control of prosecutors, who are either elected or appointed by and accountable to elected officials. Unfortunately, for reasons mentioned in section two, we should expect that the ability of this constraint to prevent domination is limited: citizens can't keep up with every criminal prosecution, which prosecutions they do keep up with is heavily influenced by arbitrary factors (like which cases the media thinks will draw viewers), they may not pay enough attention to a prosecution to recognize it as an abuse of power, they may agree with an abuse of power directed against members of a minority group, and they may, for other political reasons, not unseat a prosecutor who engages in some abuses. (Do you even know who your local DA is, much less whether they're doing a good job?) Further, where prosecutors are elected, they seldom even face credible opponents: incumbents run unopposed in $84 \%$ of elections, and when there is a challenger, they win only $18 \%$ of the time (Hughes 2017). As Evan Hughes notes, this is partly because the DA:

...is so powerful. Challengers tend to come from the local pool of lawyers with criminal experience. That means they are often defense attorneys, and should they be defeated, for years they will be constantly facing off against the DA's office that they attacked on the campaign trail. On other occasions, a lawyer mounts a challenge from inside the DA's office, which is, needless to say, a bold career move... the incumbent often enjoys a significant fundraising advantage, too; establishment figures, including opposing counsel, have an incentive to donate to the incumbent to maintain good relations or curry favor (Hughes 2017).

Thus, the very problem at hand-the excessive discretionary power of prosecutors-is part of the reason why democratic controls are ineffective at solving that problem.

A second institutional constraint is found in the grand jury system. Grand juries are meant to prevent spurious prosecutions by allowing cases to go to trial only upon finding probable cause that a crime has been committed. But clearly, this is not much help under conditions of

\footnotetext{
${ }^{10}$ There is actually at least one more such feature: professional disciplinary measures, such as being disbarred by the bar association in one's state. The Supreme Court, in upholding prosecutorial immunity, has claimed that such measures help provide an adequate check against misconduct (Keenan et al. 2011, 205). But in fact, these measures are mostly toothless and are almost never employed, even where prosecutorial misconduct is egregious. For an extensive discussion and explanation of this fact, see Keenan et al. 2011.
} 
universal criminalization, given that these conditions make it very easy to find probable cause that someone has committed some crime or other. And grand juries are an extremely weak check against spurious prosecutions, anyway. Since an indictment only requires a simple majority of jurors, and since only the prosecutor is allowed to make a case, securing an indictment is extremely easy (Fouts 2004, 326-330); in some years, federal grand juries refuse to indict in only a few dozen out of tens of thousands of cases (329-330). Accordingly, grand juries do relatively little to provide a check against domination (cf. Reynolds 2013, 106).

A third constraint is the "selective prosecution" defense. It claims the defendant is being targeted for prosecution on a constitutionally prohibited ground, and that the charges against them should therefore be dismissed (Reiss 1987, 1369-1370; for thorough overviews of relevant law, see Jampol 1997, 933-941 and Kruse 2005, 1527-1534). There are:

...effectively three impermissible bases for prosecutorial selectivity, that is, three factors that may not motivate a prosecutor to proceed against a particular defendant: (1) race, religion, or other suspect classification; (2) a desire to impede the exercise of constitutional, usually first amendment, rights; and (3) personal animosity towards the defendant (Reiss 1987, 1372).

Unfortunately, existing jurisprudence makes mounting a successful selective prosecution defense nearly impossible. Consider the claim that one was targeted for prosecution on the basis of race. Depending on how one interprets certain rulings, the number of successful racebased selective prosecution defenses mounted at the state and federal level in the twentiethcentury appears to be somewhere between two and zero (Jampol 1997, 965; Chin 2007, 1361; McAdams 1998, 616, fn. 55), even though the historically informed will suspect that there were somewhat more instances of racially-motivated prosecutions in the US during this period. ${ }^{11}$ Richard H. McAdams $(1998,606)$ writes that the current legal regime, by making it so hard to prove even meritorious selective prosecution claims, "can be justified only by great hostility to the selective prosecution doctrine itself, by placing an extremely low, or negative, value on the vindication of meritorious claims."12

Selective prosecution defenses are so difficult partly because they must show both a discriminatory effect (i.e., that other, "similarly situated" individuals were not prosecuted) and discriminatory intent (i.e., that the prosecutor's reason for targeting the defendant was impermissible) (Kruse 2005, 1525). But this is extremely difficult:

Because of the myriad of factors that could affect a prosecutor's decision to bring charges, including the strength of the evidence, the culpability of the offender, and the need to send out various enforcement signals, courts are generally unwilling to infer a discriminatory intent from nonenforcement statistics alone. Yet it is usually difficult to get evidence of discriminatory intent beyond such statistics. Prosecutors do not have to explain their decision to bring or refrain from bringing charges and many prosecution offices lack even general guidelines governing charging decisions. Consequently, there is usually little in the way of documented administrative decision making for a defendant

\footnotetext{
${ }^{11}$ In fact, the Yick Wo case, from 1886, is generally taken to have established the possibility of a race-based selective prosecution defense, but whether this was actually the court's reason for siding with Yick Wo is controversial (cf. Chin 2007). If it wasn't, then there may have never been a successful race-based selective prosecution defense.

${ }_{12}$ McAdams (1998, 641) suggests that one might defend the hostility by claiming that "selective prosecution is extremely rare," and argues against this claim (642-652). Of course, my argument implies that, even if it is extremely rare, that prosecutors could engage in it with impunity constitutes problematic domination.
} 
to utilize. What evidence exists is generally within the prosecutor's control (Reiss 1987, 1373). ${ }^{13}$

Where such evidence is within the prosecutor's possession, courts can compel prosecutors to hand it over to the defense by ordering discovery. But for defendants to obtain discovery in a selective prosecution case, they must provide evidence of discriminatory effect and intent which meets "a very high threshold," one so high as to "practically merge the requirements for obtaining discovery in a selective prosecution claim with the threshold for proving such a claim on the merits" (Jampol 1997, 954). In order to obtain discovery, the defendant must therefore produce evidence of a type which can usually only be acquired through discovery, and is "thus placed in a Catch-22 type bind" (Reiss 1987, 1373). So this also provides little defense against domination.

\section{Possible Solutions}

I now survey some possible solutions to the problem of prosecutorial domination. It may help to reiterate the argument of section three, since most of these solutions are aimed at alleviating the particular features which give rise to prosecutorial domination. The argument was that prosecutors possess tremendous, largely unchecked discretionary power in virtue of:

\section{A. Universal criminalization, which obtains in light of:}

1. The vast number of laws,

2. The scope of these laws,

3. The vagueness of many laws, and

4. The proliferation of crimes without strong mens rea requirements;

\section{B. Further exacerbating features, including:}

1. The fact that "the process is punishment,"

2. The plea bargain system, and

3. Prosecutorial immunity;

C. The failure of existing checks on prosecutorial power, including:

1. Democratic accountability,

2. Grand juries,

3. The selective prosecution defense.

Together, these facts mean that many ordinary people are such that prosecutors could interfere with relative impunity in the exercise of their basic liberties. I will not make a serious attempt to evaluate the solutions I survey; doing so would require a fair amount of empirical investigation of the sort which I have neither the expertise nor the space to do. Of course, showing that we should implement these proposals would require, not only showing that they will have the desired effect, but also that they will not have other, even more undesirable

${ }^{13}$ Reiss focuses on the difficulty of proving discriminatory intent, but it is also often extremely difficult to obtain sufficient evidence of discriminatory effect without discovery being ordered; see McAdams 1998. 
effects. (John Braithwaite and Philip Pettit (Braithwaite and Pettit 1992, 115-119) have even offered a limited republican defense of prosecutorial discretion on the grounds that it allows prosecutors to avoid prosecuting when doing so would set back the cause of republican freedom on balance.) One point in favor of the package of proposals I explore is that, as should become clear, some of them have already been defended on independent grounds. If they will help alleviate prosecutorial domination as well as achieving other goals, vindicating them will obviously be easier. Relatedly, Braithwaite and Pettit (1992, ch. 7) have argued for a "decremental" approach to implementing republican legal reforms. They claim that, given the current situation in most Western nations, we can gradually scale back the criminal justice system ("decrease the size of the police force, prosecute less, punish less" (140)) without serious risk of increased crime, halting such reforms if the risks increase. Some of these proposals may be in line with this overall framework.

Some measures might attempt to strengthen the existing safeguards against prosecutorial misconduct. For instance, public financing of campaigns might help obviate the fundraising advantage possessed by incumbent, and therefore make elections more competitive. Or, as Glenn Harlan Reynolds suggests, grand juries might be reformed so that "jurors might, for example, be given extensive training, or be given counsel and investigators of their own" (Reynolds 2013, 106, fn. 16). Yet another option would make pursuing a selective prosecution defense easier, perhaps, say, by lowering the standard for obtaining discovery (Jampol 1997; McAdams 1998), or altering the evidential standards which must be met to show discriminatory intent (Reiss 1987, 1443-1452). However, for various reasons-some of which have already been indicated-such measures alone aren't likely to solve the problem of prosecutorial domination. (Such reasons include, e.g., that electorates can't keep up with every trial, that grand juries, legally speaking, should indict when the prosecution shows probable cause of a crime, even if universal criminalization makes doing so too easy, and that even a biased prosecutor may cover their tracks well enough to avoid a selective prosecution defense, and will still have put the defendant through a punishing process even without a conviction.) So it's worth considering other ways of checking prosecutorial power.

We might directly target the factors that make for universal criminalization itself: the number of criminal laws, the scope of criminal laws, the vagueness of some laws, and the lack of mens rea requirements in some laws. Reynolds $(2013,107)$ suggests that it is "worth considering whether mere regulatory violations... should bear criminal sanctions at all." This is perhaps of a piece with Henry M. Hart's $(1958,411)$ suggestion that the constitution might be amended to include "substantive limitations on the kinds of conduct that can be declared criminal." These proposals would drastically cut down on the number and scope of criminal laws, and so ameliorate the first two factors leading to universal criminalization. And reducing the scope of the criminal law has already been defended by Pettit and Braithwaite (Braithwaite and Pettit 1992, 92-101) on independent republican grounds.

Yet another option would be to address the vagueness found in many laws. As mentioned, the vagueness doctrine is already intended to prohibit the enforcement of unreasonably vague laws; perhaps some new, and more effective, test for vagueness could be devised. Or perhaps Congress could be persuaded to address vague laws on a case by case basis, making them more precise and less susceptible to abuse. Further, we might address crimes which lack mens rea requirements, most obviously by just adding them. (Pettit and Braithwaite (Braithwaite and Pettit 1992, 99-101) argue that republicans should oppose "absolute liability" crimes on independent grounds.) Michael Cottone (2014) suggests going further by reconsidering the doctrine of "presumed knowledge of the law." While presumed knowledge might be 
appropriate in the case of common law offenses, when it comes to regulatory crimes which govern ordinary activities, prosecutors might be required to show that the defendant knew, or should have known, about the law that they broke. Finally, we might reduce criminal penalties-perhaps imposing more and lower maximum sentences (cf. Braithwaite and Pettit 1992, 101-106), or eliminating or raising minimum sentences, for various crimes. This would not, itself, reduce prosecutors' opportunities to charge individuals. But it might reduce the impact of that decision, as well as lowering their ability to compel a defendant to accept a plea bargain through overcharging.

Other measures might target the "extenuating circumstances" mentioned in section 4.2: the fact that the process is punishment, that plea bargains mean most cases are never even tried in court, and the fact that prosecutors are immune to being sued for misconduct. Several possibilities are suggested by Glenn Harlan Reynolds. One (Reynolds 2013, 106) is a " loser pays' rule for criminal defense costs," according to which the prosecutor's office must reimburse the defendant's legal fees if they are acquitted. This would help ameliorate the threat posed by the fact that the "process is punishment," since innocent defendants would at least be spared some of the financial costs of the trial, and since prosecutors would have a financial incentive not to harass defendants with indefensible charges. Another might be reforming or even eliminating the bail system. For instance, defendants who are judged a flight or safety risk might be imprisoned, and the rest released without needing to make bail. Something like is currently done in Washington, D.C.: upwards of $80 \%$ of defendants are released, and $88 \%$ of those released show up for their court dates (Ingraham 2015).

Reynolds $(2013,107)$ also suggests the system might be "pro-rated," so that if you charge "a defendant with twenty offenses, but convict on only one," you must "bear $95 \%$ of the defendant's legal fees." This might help limit abuses of the plea bargaining system: because prosecutors would have an incentive to not just charge the defendant with everything they could think of, the possible consequences for the defendant of going to trial would be lessened. Yet another way of addressing abuses of plea bargaining involves requiring "that the prosecution's plea offers be presented to a jury or judge after a conviction, before sentencing" (107). If a prosecutor offers a light sentence during plea bargaining but demands a much harsher sentence at trial, a jury might be less likely to hand down the harsher sentence if they know the prosecutor was willing to accept a much lighter one. A further, "nuclear option" might be banning plea bargains altogether (ibid.) Meanwhile, evoking or limiting prosecutorial immunity, and thereby opening up prosecutors to liability for misconduct, might help provide citizens with a recourse against abuses. Reynolds (106) suggests that "even a shift to qualified, good faith immunity for prosecutors"-which would leave them open to liability for actions taken in bad faith-"would change the calculus significantly, making subsequent review something that is at least possible."

Additionally, consider the suggestion, discussed in section two, that prosecutorial power is problematic wholly or partly for those at especially high risk of suffering from its abuse-either because only they meet the probabilistic threshold to count as having "good reason to be anxious," or because being under the power of others is problematic only when, and because, it reinforces unjust social hierarchies. In that case, we might take measures to address the disparities which put these people at special risk. For instance, we might attempt to address racial disparities in policing which put minorities at greater risk of coming to a prosecutor's attention, the differential treatment they receive from prosecutors themselves, and subsequent disparities (for instance, in convictions or sentencing) which amplify the impact of earlier disparities. Addressing racial disparities in the justice system is obviously its own immense 
topic which I cannot delve into it, but the literature contains many suggestions about steps which might be taken (e.g., "Reducing..." 2008, 25-61; Yankah 2013, 2019), and, again, addressing these disparities is advisable anyway.

Finally, I'll note that the US might be able to learn important lessons from the legal systems of other nations. Of particular note is Germany, where prosecutors are constrained by far more bureaucratic checks and where they are commonly regarded as "the most objective civil servants in the world" (Boyne 2014, 6-7). The principle of mandatory prosecution is meant to severely curtail prosecutorial discretion: it requires that, for serious crimes, prosecutors "file charges in all cases in which sufficient evidence exists to believe that a crime has been committed," in order "to ensure that prosecutors enforce the law in a uniform and nonarbitrary manner" (ibid.) Traditionally, plea bargaining has not been allowed, and is still prohibited for serious crimes (11). By law and professional ethos, German prosecutors are meant to be impartial, quasi-judicial agents aimed at finding the truth, rather than members of an adversarial process with the aim of acquiring a conviction (6-7). Further, their status as civil servants with lifetime appointments, rather than elected officials or political appointees, is meant to insulate them from political pressure (6).

I will say three things about learning from the German legal system: one is about potential limitations of this approach, one is about the negative examples it sets, and one is about the positive examples it sets. First comes the limitation. Certain features of the German system, even if desirable from the perspective of ideal theory, may be of little use from the perspective of transitional theory. For instance, I suspect that radically restructuring the role of prosecutors to more resemble that of the German system would be politically and logistically impractical. It may be better, then, to focus on more "actionable" proposals.

Second, the German example can make us aware of certain potential pitfalls. In practice, the German system has not always followed its intended design. Over time, resource constraints have increased the scope of prosecutorial discretion-prosecutors simply cannot launch detailed investigations of all the cases which come to their attention-with the expanded use of discretion in practice often coming before legislative changes allowing it (65-70). Similarly, the use of "confession agreements"-the German equivalent of plea bargaining-has increased over time, in a similar way and for similar reasons (9-10). Further, while there are strict regulations concerning confession agreements, these are often not followed in practice (BVerfG 2013, sec. V). While the exercise of discretion and the use of confession agreements is (in theory) largely restricted to "low-level" (Vergehen) crimes, this category is actually very broad-much broader than the Anglo-American category of misdemeanors-including more than $85 \%$ of the crimes committed on an annual basis (Boyne 2014, 71). And even in the case of serious crimes, prosecutors must exercise a certain amount of discretion, for instance, in deciding how much effort to put into collecting evidence in a case (95-96; 104-107; chs. 6-8). These factors suggest that certain drastic reforms to the American system, such as eliminating prosecutorial discretion or plea bargains-whatever their other merits or demerits-are not likely to solve the problem on their own, if only because resource limitations are likely to prevent their full and consistent implementation (at least absent other reforms, such as narrowing the scope of the criminal law).

Further, despite their ostensible role as apolitical, objective investigators, German prosecutors are in practice still affected by legally arbitrary incentives, such as "informal" suggestions from superiors with a political agenda (which may be backed by the threat of transferring the prosecutor to a less desirable position) and the preference for maintaining good working relationships with one's colleagues and with members of the police and judiciary (108-115). 
Among other things, this might help show that, even if we are sympathetic to a form of republicanism which says that civic virtue, rather than external constraints, can prevent domination (cf. sec. 2), we may also want to employ external constraints simply on grounds of effectiveness.

Third, even though the German system does not always function as designed, it nonetheless provides some reason for thinking that effectively designed institutions really can reduce the arbitrary use of legal power. Some examples: the principle of mandatory prosecution does seem to help shield prosecutors from political influence (109-110). As a percentage of cases, resolution by confession agreement is much less common in Germany than is resolution by plea bargain in the US, and the regulations governing confession agreements are followed much of the time (BVerfG 2013, sec. V). Further, comparatively strict constraints on the pretrial detention of subjects (Boyne 2014, 133-134) help mitigate the extent to which "the process is punishment." Perhaps adapting some of these successful elements insofar as is possible, in addition to implementing some of the other suggestions above, could help mitigate the problem of prosecutorial domination. Of course, I haven't explored everything we might learn from the German example, much less everything we might learn from considering other legal systems. That is a matter for future research.

\section{Conclusion}

Taken together, an array of features present in the US legal system give prosecutors tremendous, and to a large extent unrestrained, power to interfere with relative impunity in the lives of ordinary citizens. They can directly interfere with the exercise of basic freedoms (for instance, by imprisoning someone), and can deter individuals from taking certain actions because of the threat of retaliation. On the republican conception, their merely possessing this power constitutes an egregious and widespread injustice, regardless of how often it is abused. Neither democratic accountability nor the grand jury system nor the selective prosecution defense have effectively reined in prosecutorial power. Just as bureaucracy in general is needed to ensure that officials are governed by the rule of law and therefore possess power which is "not arbitrary, but limited to the ends of office" (Anderson 2008, 155), heightened institutional checks on prosecutorial power are needed to ensure that the power of prosecutors is limited to the ends of office. I surveyed some potential measures in section four. These measures, and perhaps others like them, ought to be investigated further.

Acknowledgements Open Access funding provided by Projekt DEAL. I am grateful to Will Smith, Paul Weithman, and especially to Rebecca Chan for comments on this paper. This paper received funding from the European Research Council (ERC) under the European Union's Horizon 2020 research and innovation programme (grant agreement No. 786762).

Open Access This article is licensed under a Creative Commons Attribution 4.0 International License, which permits use, sharing, adaptation, distribution and reproduction in any medium or format, as long as you give appropriate credit to the original author(s) and the source, provide a link to the Creative Commons licence, and indicate if changes were made. The images or other third party material in this article are included in the article's Creative Commons licence, unless indicated otherwise in a credit line to the material. If material is not included in the article's Creative Commons licence and your intended use is not permitted by statutory regulation or exceeds the permitted use, you will need to obtain permission directly from the copyright holder. To view a copy of this licence, visit http://creativecommons.org/licenses/by/4.0/. 


\section{References}

Anderson E (2008) Expanding the egalitarian toolbox: equality and bureaucracy. Aristotelian Society Supplementary 82(1):139-160

Baker J (2008) Revisiting the Explosive Growth of Federal Crimes. Washington, D.C.: Heritage Foundation. Accessed 8-22-2018 from https://www.heritage.org/report/revisiting-the-explosive-growth-federal-crimes

Barnes, Robert (2010). "Supreme Court Upholds Ban on 'Material Support' to Foreign Terrorist Groups." Washington Post. Accessed 8-22-2018 from http://www.washingtonpost.com/wp-dyn/content/article/2010 /06/21/AR2010062101811.html?sid=ST2010062104796\&noredirect=on

Boyne SM (2014) The German prosecution service: guardians of the law? Springer, New York

Braithwaite J, Pettit P (1992) Not just deserts: a republican theory of criminal justice. OUP, Oxford

Brame R, Bushway SD, Paternoster R, Turner MG (2014) Demographic patterns of cumulative arrest prevalence by ages 18 and 23. Crime Delinq 60(3):471-486

(2015)"Buying Firewood in New Mexico? Know the Law So You Don’t Get Burned." New Mexico Department of Agriculture. Accessed 8-22-2018 from http://www.nmda.nmsu.edu/2015/11/buying-firewood-in-newmexico-know-the-law-so-you-dont-get-burned/

BVerfG, Judgment of the Second Senate of 19 March 2013-2 BvR 2628/10 -, paras. (1-132). Retrieved 4-29-20 from http://www.bverfg.de/e/rs20130319 2bvr262810en.html

Chin GL (2007) Unexplainable on grounds of race: doubts about Yick Wo. Univ Ill Law Rev 2008:1359-1392

Cottone M (2014) Rethinking presumed knowledge of the law in the regulatory age. Tennessee Law Review 82: $137-166$

Fields G, Emshwiller JR (2011). A Sewage Blunder Earns Engineer a Criminal Record. Wall Street Journal. Accessed 822-2018 from https:/www.wsj.com/articles/SB10001424052970204903804577082770135339442

Fouts GT (2004) Reading the jurors their rights: the continuing question of grand jury Independence. Indiana Law J 79(1):323-344

Greenwald G (2011). Government-Created Climate of Fear. Salon. Accessed 8-22-2018 from https://www.salon. com/2011/01/10/fear 12/

Hart HM (1958) The aims of the criminal law. Law and Contemporary Problems 23(3):401-441

Healy G (ed) (2004) Go directly to jail: the criminalization of almost everything. Cato Institute, Washington, D.C.

Hughes E (2017) America's Prosecutors Were Supposed to Be Accountable to Voters. What Went Wrong? Politico. Accessed 8-22-2018 from https:/www.politico.com/magazine/story/2017/11/05/cyrus-vance-jramericas-prosecutor-problem-215786

Husak D (2016) Ignorance of law: a philosophical inquiry. Oxford University Press, Oxford

Ingraham C (2015) Why We Spend Billions to Keep Half a Million Unconvicted People Behind Bars. Washington Post. Accessed 8-22-2018 from https:/www.washingtonpost.com/news/wonk/wp/2015/06/11 /why-we-spend-billions-to-keep-half-a-million-unconvicted-people-behind-bars/?utm term=.b2658f39e19c

Jackson R (1940) The Federal Prosecutor. Journal of the American Judicature Society 24:18-20

Jampol ML (1997) Goodbye to the defense of selective prosecution. Journal of Law and Criminology 87:932966

Keenan D et al (2011) The myth of prosecutorial accountability after Connick vs. Thomson: why existing professional accountability measures cannot protect against prosecutorial misconduct. Yale Law J 121:203265

Kolodny N (2019) Being Under the Power of Others. Republicanism and the Future of Democracy, ed. by Yiftah Elazar and Geneviève Rousselière: 94-114. Cambridge: Cambridge University Press

Kozinski A, Tseytlin M (2009) You're (probably) a Federal Criminal. In the Name of Justice: Leading Experts Reexamine the Classic Article "The Aims of the Criminal Law." Washington, D.C.: Cato Institute

Kruse KE (2005) Proving discriminatory intent in selective prosecution challenges - an alternative approach to United States v. Armstrong. SMU Law Review 58:1523-1550

Lynch T ed. (2009) In the Name of Justice: Leading Experts Reexamine the Classic Article "The Aims of the Criminal Law." Washington, D.C.: Cato Institute

McAdams RH (1998) Race and selective prosecution: discovering the pitfalls of Armstrong. Chicago-Kent Law Review 73:605-667

Owens E et al. (2017) Examining Racial Disparities in Criminal Case Outcomes among Indigent Defendants in San Francisco. University of Pennsylvania School of Law. Retrieved 4-29-20 from https://www.law.upenn. edu/live/files/6793-examining-racial-disparities-may-2017-full

Pettit P (2012) On the People's terms: a republican theory and model of democracy. Cambridge University Press, Cambridge

(2008) "Reducing Racial Disparity in the Criminal Justice System: A Manual for Practitioners and Policymakers." The Sentencing Project. Retrieved 4-29-20 from https://www.sentencingproject.org/wp- 
content/uploads/2016/01/Reducing-Racial-Disparity-in-the-Criminal-Justice-System-A-Manual-forPractitioners-and-Policymakers.pdf

Reiss SA (1987) Prosecutorial intent in constitutional criminal procedure. Univ Pa Law Rev 135:1365-1477

Rehavi MM, Starr SB (2014) Racial disparity in Federal Criminal Sentencing. J Polit Econ 122(6):1320-1354

Reynolds GH (2013) Ham Sandwich nation: due process when everything is a crime. Columbia Law Review 113:102-108

Reynolds GH (2015) You Are Probably Breaking the Law Right Now. USA Today. Accessed 8-22-2018 from https://www.usatoday.com/story/opinion/2015/03/29/crime-law-criminal-unfair-column/70630978/

(2018) "The Trial Penalty: The Sixth AMendment Right on the Verge of Extinction and How to Save It." National Association of Criminal Defense Lawyers. Retrieved 8-15-2020 from https://www.nacdl. org/getattachment/95b7f0f5-90df-4f9f-9115-520b3f58036a/the-trial-penalty-the-sixth-amendment-right-totrial-on-the-verge-of-extinction-and-how-to-save-it.pdf

Simpson T (2017) The impossibility of republican freedom. Philos Public Aff 45(1):27-53

Silverglate H (2009) Three felonies a day: how the feds target the innocent. Encounter Books, New York

"Vagueness Doctrine." Legal Information Institute, Cornell School of Law. Accessed 8-22-2018 from https://www.law.cornell.edu/wex/vagueness doctrine

Wu T (2007) American Lawbreaking. Slate. Accessed 8-22-2018 from http://www.slate.com/articles/news_and politics/jurisprudence/features/2007/american_lawbreaking/introduction.html

Yankah E (2013) Policing Ourselves: A Republican Theory of Citizenship, Dignity, and Policy-A Comment on Fagan. Retrieved 4-29-20 from https://papers.ssrn.com/sol3/papers.cfm?abstract id=2258048

Yankah E (2019) Pretext and justification: republicanism, policing, and race. Cardazo Law Review 40(4):15431637

Yoffe E (2017) Innocence is Irrelevant in the Age of the Plea Bargain. The Atlantic. Accessed 8-22-2018 from https://www.theatlantic.com/magazine/archive/2017/09/innocence-is-irrelevant/534171/

Publisher's Note Springer Nature remains neutral with regard to jurisdictional claims in published maps and institutional affiliations. 